\title{
Reappraisal of alcoholic myopathy' Clinical and biopsy study on chronic alcoholics without muscle weakness or wasting
}

\author{
AMIN A. FARIS ${ }^{2}$ AND MARCELINO G. REYES 3 \\ From the Division of Neurology and Department of Pathology, University of Missouri School \\ of Medicine at Kansas City General Hospital and Medical Center, Kansas City, Missouri, U.S.A.
}

SUMMARY To determine if alcoholic neuropathy which causes denervation of the distal muscles of chronic alcoholics also produces a subclinical myopathy of their proximal muscles, we studied ${ }^{\infty}$ 11 chronic alcoholics who had no muscular weakness or wasting. Six patients demonstrated distal. hyporeflexic (ankle jerks) sensory neuropathy on clinical examination. Four patients, one of whom $\vec{\omega}$ was asymptomatic, had slow peroneal motor nerve conduction velocities. Patterns of neuropathy were present in the electromyograms of the proximal muscles of two patients. Muscle biopsy studies with enzyme histochemistry indicated denervation atrophy and myopathic changes in the contra- $\frac{-0}{\omega}$ lateral quadriceps muscles of eight patients. As denervation atrophy was present, we concluded that ${ }^{+}$ these myopathic changes represented the effects of denervation of these muscles. We conclude, $\vec{\infty}$ therefore, that the proximal subclinical alcoholic myopathy, previously described as primary ourselves and others, is the result of denervation due to the well-known alcoholic neuropathy.

Hed, Lundmark, Fahlgren, and Orell in 1962, described a reversible acute myopathy related to the excessive use of alcohol. This myopathy was characterized by proximal muscle weakness, cramps, tenderness, swelling, and, in some patients, by myoglobinuria. Histological study demonstrated vacuolation and necrosis with secondary inflammation of muscle fibres. In 1964 Ekbom, Kirstein, and Astrom studied a group of chronic alcoholics who presented with weakness and wasting of their proximal muscles. Electromyograms and muscle biopsies confirmed the presence of a myopathy. These same electromyographic and histopathological features were also present in a group of asymptomatic chronic alcoholics. In 1966 Mancall, McEntee, Hirschhorn, and Gonyea, contended, on the basis of muscle biopsy and electrodiagnostic findings, that their patients had a primary myopathy of their proximal muscles as well as an unrelated secondary

${ }^{1}$ Supported in part by U.S.P.H.S. grant NB-05457-03 and a grant of the Medical Staff Fund.

${ }^{2}$ Present address: Baptist Memorial Hospital, Memphis, Tennessee, U.S.A.

${ }^{3}$ Present address and for reprints: Department of Neurology, Chicago Medical School, 2020 West Ogden Street, Chicago, Illinois, U.S.A. myopathy of their distal muscles. Because the secondary myopathy resulted from denervation caused by the well-known alcoholic neuropati, $\overrightarrow{0}$ they concluded that primary alcoholic myopathy differed from alcoholic neuropathy and that both disorders may occur in the same patient. Perkoff, Hardy, and Velez-Garcia (1966) and Perkoff, Dioso, Bleisch, and Klinkerfuss (1967) demonstrated high serum creatine phosphokinase, low serum phos- $\frac{\circ}{\circ}$ phorylase, and poor lactic acid response to ischaemic exercise in their patients with alcoholic myopathy. $\overrightarrow{0}$ Assuming that these changes were the result of the toxic effects of alcohol on muscle, they argued for a primary alcoholic myopathy. However, most of their patients also had distal neuropathies.

We presented a preliminary report on subclinicalo alcoholic myopathy in 1967 (Faris, Reyes, and Abrams, 1967). Twenty-four chronic alcoholics:without proximal or distal muscle weakness, $\stackrel{0}{\circ}$ atrophy, fasciculations, tenderness, or cramps were studied. Neurological examination, however, showed음 absent or diminished ankle jerks in 20 patients who, $>$ on direct questioning, also admitted having episodeso of burning feet or distal paraesthesias. Decreased conduction velocities of their distal motor and sensory nerves confirmed the presence of distal ${ }_{0}$ neuropathy in each of these patients. Some of them 
also had electromyographic patterns of neuropathy in the muscles of their hands and feet. Electromyograms of their proximal quadriceps or biceps muscles however, did not indicate neuropathic patterns. Instead, in 18 patients we found patchily distributed low-voltage, short-duration, often polyphasic potentials and occasional paradoxical recruitment on minimal voluntary effort. These changes are consistent with a primary myopathy.

Similarly, no histological signs of denervation were found in the contralateral proximal muscles of the 24 patients. Instead, 17 patients had the following abnormalities: increased numbers of sarcolemmal nuclei; internal nuclei; random variation in fibre size; occasional vacuolated, necrotic or basophilic fibres; and fatty tissue replacement of some fibres. Muscle biopsy changes such as these, in the absence of denervation atrophy, are highly indicative of primary myopathy. Our study therefore suggested that subclinical myopathy of the proximal muscles of chronic alcoholics occurs more frequently than the literature implies and that such involvement probably results from a primary myopathy.

We did not, however, dismiss the possibility that the denervation associated with alcoholic neuropathy could have caused the proximal subclinical myopathy in our patients. Bauwens (1961) and Taverner (1961) found, in their patients with distal neuropathies, electromyographic patterns identical with those present in the proximal muscles of our patients. Drachman, Murphy, Nigam, and Hills (1967) demonstrated that, not infrequently, the chronically-denervated muscle will show only the classical histological signs of primary myopathy. These include, in addition to those described in our patients: fibre splitting, ring fibres, and endomysial fibrosis. None of these histological changes are, however, specific for a primary myopathy.

Our studies in the hamster, and those in the cat of Engel, Brooke, and Nelson (1966), have shown that denervation can cause changes which are indistinguishable from primary myopathy except for the presence of group fibre atrophy and other enzyme histochemical signs of denervation. In other words, denervation can mimic all the histological signs of a primary myopathy. Therefore, to diagnose a primary myopathy, we had first to prove that the muscle biopsy changes were not the result of denervation. As denervation atrophy was absent in the biopsies of our patients, we diagnosed a primary myopathy of their proximal muscles, although they also had distal neuropathies.

However, because the formalin-fixed, paraffinembedded sections we used do not allow as much clarity of histological or cytological details as do fresh-frozen sections, it is possible that we over- looked small groups of atrophic fibres in our biopsies. To eliminate this possibility, we have repeated our studies in a group of chronic alcoholics without muscle weakness or wasting, using fresh-frozen muscle biopsy techniques and enzyme histochemistry. In this manner, we are better able to judge what role denervation plays in subclinical alcoholic myopathy.

\section{PATIENTS}

Eleven chronic alcoholics who participated in the Rehabilitation Program of the Alcoholic Unit of Western Missouri Mental Health Center were studied. These patients, 10 males and one female, ranged in age from 39 to 65 years and had well-documented histories of chronic alcoholism of 10 to $\mathbf{4 0}$ years duration (measured from the time they 'lost control' of their drinking, the point that we consider differentiates the heavy social or problem drinker from the true alcoholic). Nine patients had had at least one episode of delirium tremens. None of them had any family history of neuromuscular or other neurological diseases. We found no abnormalities on physical or neurological examination with the exception of absent or diminished ankle jerks in four patients. Two of these patients also complained of occasional burning, tingling, or 'pins and needles' in their feet and hands. Two other patients complained of the distal paraesthesias only.

\section{RESULTS}

LABORATORY STUDIES All patients had normal CBC, FBS, BUN, $\mathrm{Na}, \mathrm{K}, \mathrm{Cl}, \mathrm{CO}_{2}$, total proteins, $\mathrm{A} / \mathrm{G}$ ratio, alkaline phosphatase, prothrombin time, BSP and PBI tests, except for two patients who had 8 and $32 \%$ BSP retentions at 45 minutes. Serum GOT, $\mathrm{LDH}$, and CPK were normal in all but one patient whose serial electrocardiograms indicated a silent acute myocardial infarction. The other patients had normal electrocardiograms. All the patients had normal radiographs of the chest and negative serum VDRL.

MUSCLE BIOPSY STUDIES We biopsied the right quadriceps muscle in each patient, placed the specimen in a moist chamber for $\mathbf{3 0}$ minutes to reduce its irritability, and, with a razor blade, cut out cylindrical portions, mounted them in cross-sections in cryostat chucks and froze them in chilled isopentane at $-160^{\circ} \mathrm{C}$. Serial sections at $10 \mu$ were cut and then stained with modified trichrome (Cunningham and Angel, 1963), nicotinamide-adenine dinucleotide dehydrogenase (NADH) (Novikoff, Shin, and Drucker, 1961), 'menadione-linked' alpha-glycerophosphate dehydrogenase (MAG) (Wattenberg and Leong, 1960), myosin adenosine triphosphatase (ATPase) (Padykula and Herman, 1955), and phosphorylase (Takeuchi, 1956). 
In eight biopsies, the trichrome stain showed small groups of atrophic and angular fibres (Fig. 1). Each of these biopsies also had a few fibres with internal nuclei, necrotic fibres, ring fibres, and replacement of muscle cells by fat cells. We found no other morphological abnormalities but each of the eight biopsies demonstrated abnormal enzyme histochemical reactions including an increase of the oxidative enzymes NADH or MAG and loss of phosphorylase in some of the atrophic fibres (Figs. 2 and 3). Two biopsies also demonstrated selective type II reaction of the atrophic fibres (Fig. 4). Two other biopsies, one of which had targetoid fibres, also showed type grouping (Fig. 5). There were no morphological or enzyme histochemical abnormalities in three of the muscle biopsies.

ELECTRODIAGNOSTIC STUDIES Electromyograms were performed on the contralateral quadriceps muscles of four patients, using a two-channel TECA machine and CT6M coaxial needles in tandem. Two of these patients had mild neuropathic patterns in patchy distribution such as mixed patterns on maximal voluntary effort, prolonged potentials on minimal effort and fibrillations at rest. Peroneal motor nerve conduction velocities in four patients were abnormally slow compared with those of an age-matched control group of seven healthy physicians, two of whom are abstainers and the rest light social drinkers. Their mean peroneal motor nerve conduction velocity was $47.9 \mathrm{~m} / \mathrm{sec}$ with a range of 45.5 to $51.6 \mathrm{~m} / \mathrm{sec}$. The results are tabulated in the Table.

\section{DISCUSSION}

The presence of small groups of atrophic and angular fibres in the trichrome-stained muscle $\stackrel{5}{+}$ biopsies of our patients was sufficient proof of $\bar{C}$ denervation of their proximal muscles. That muscle wasting from cachexia or disuse can mimic this atrophy pattern was of no consequence as the clinical examination had excluded these possibilities. The enzyme histochemical stains further confirmed our findings; all the biopsies with denervation atrophy had some atrophic fibres with loss of phosphorylase and an increase of the oxidative enzymes NADH or MAG. Engel (1966) considered these changes 'characteristic' of the denervated fibre but not of the atrophic cachectic or disused fibre. Similarly, other corroborative enzyme histochemicat signs of denervation were present: targetoid fibresp type grouping and selective type II reaction of the atrophic fibres.

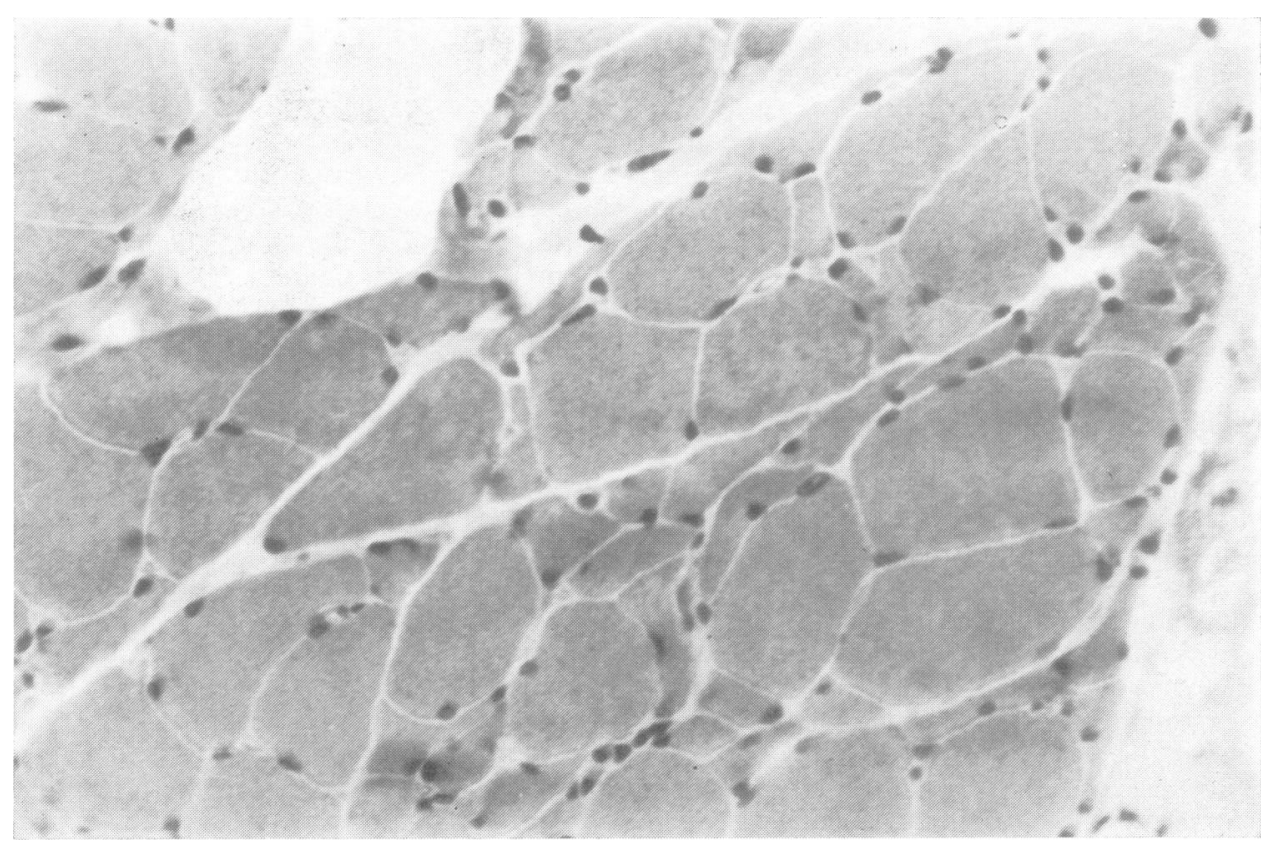

FIG. 1. Group atrophy of the quadriceps muscle of a 45 year old man with a 16 year history of chronic alcoholism. Modified trichrome, $\times 250$. 


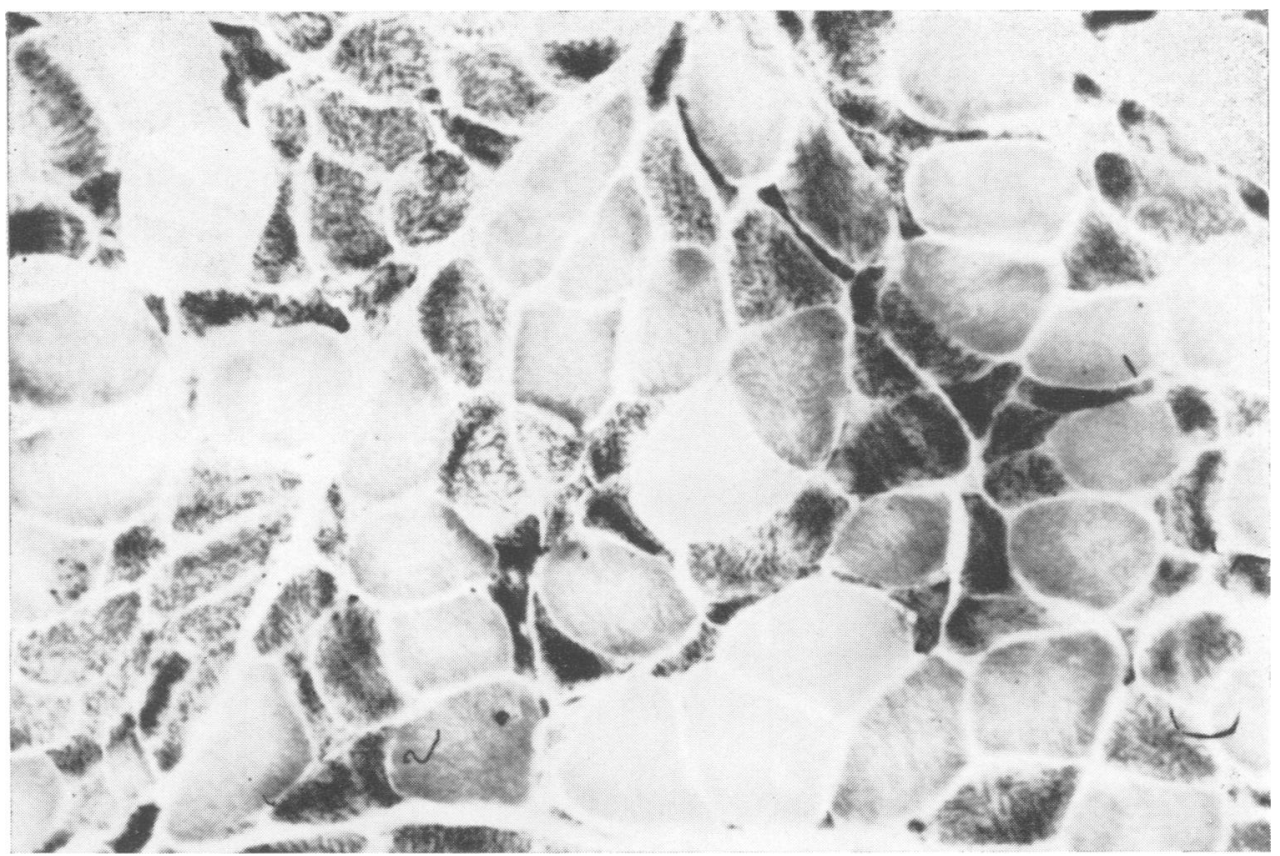

FIG. 2. Atrophic fibres with increased oxidative enzymes in another area of the muscle shown in Fig. 1. $N A D H, \times 100$.

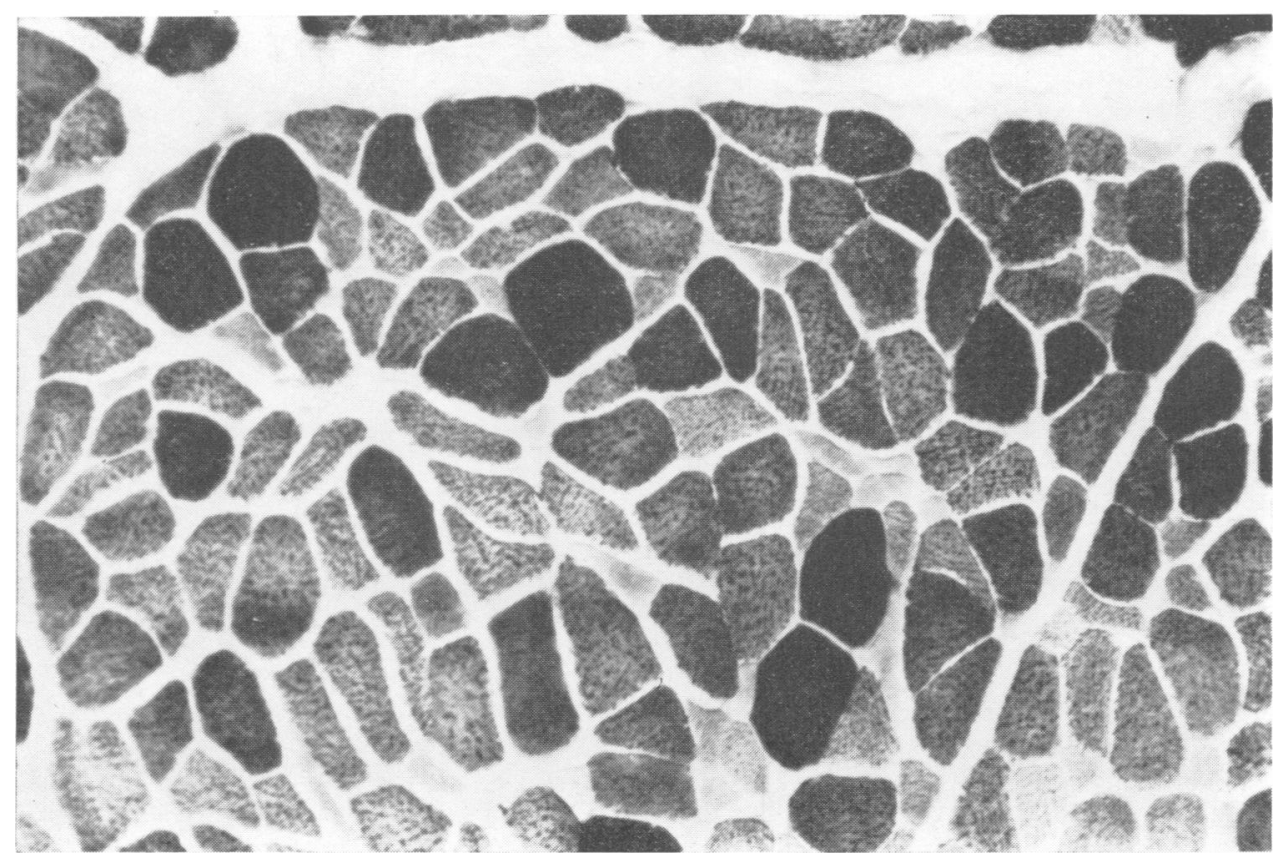

FIG. 3. Atrophic fibres with loss of phosphorylase in muscle shown in Fig. 1. Phosphorylase, $\times 100$. 


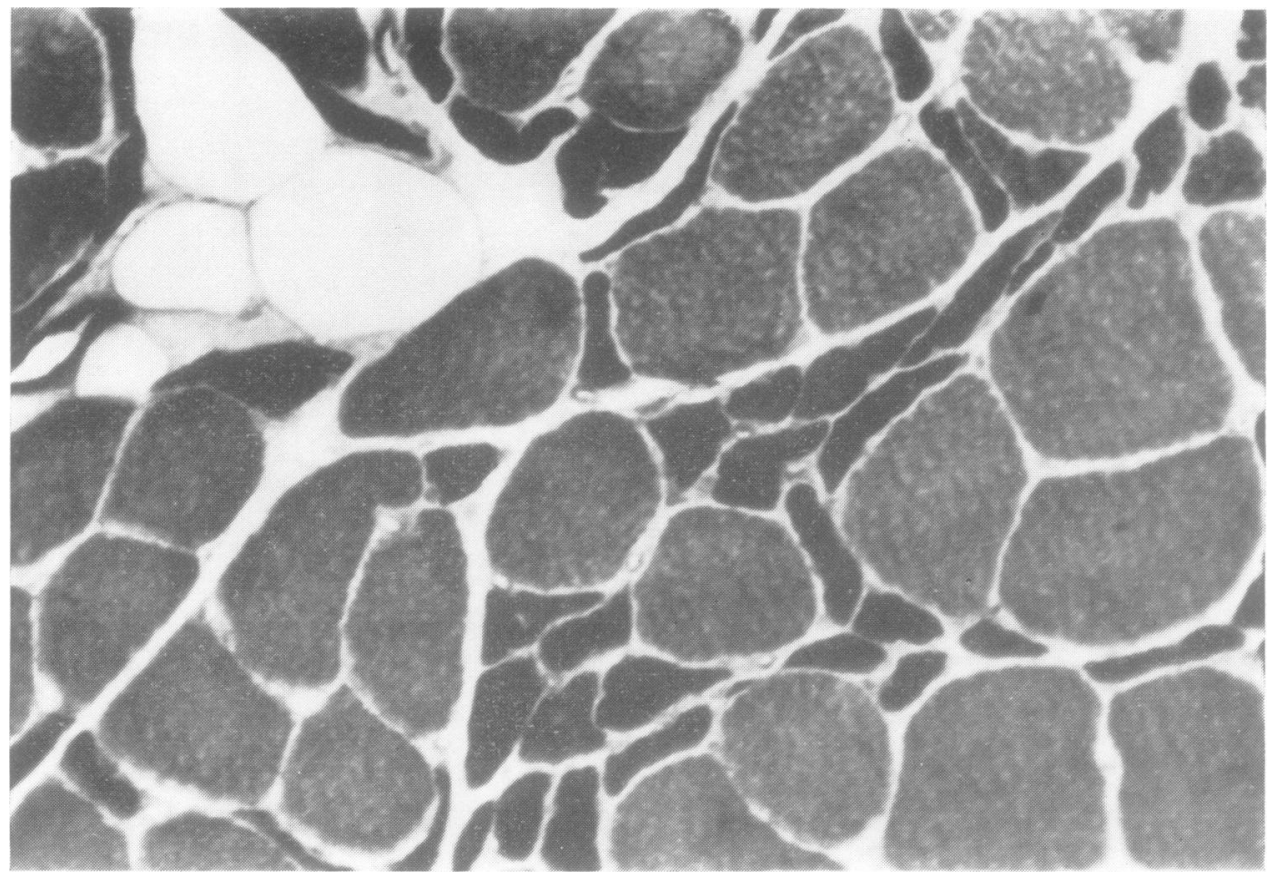

FIG. 4. Homologous area of the muscle shown in Fig. I demonstrating selective type II reaction of the atrophic fibres. ATPase, $\times 250$.

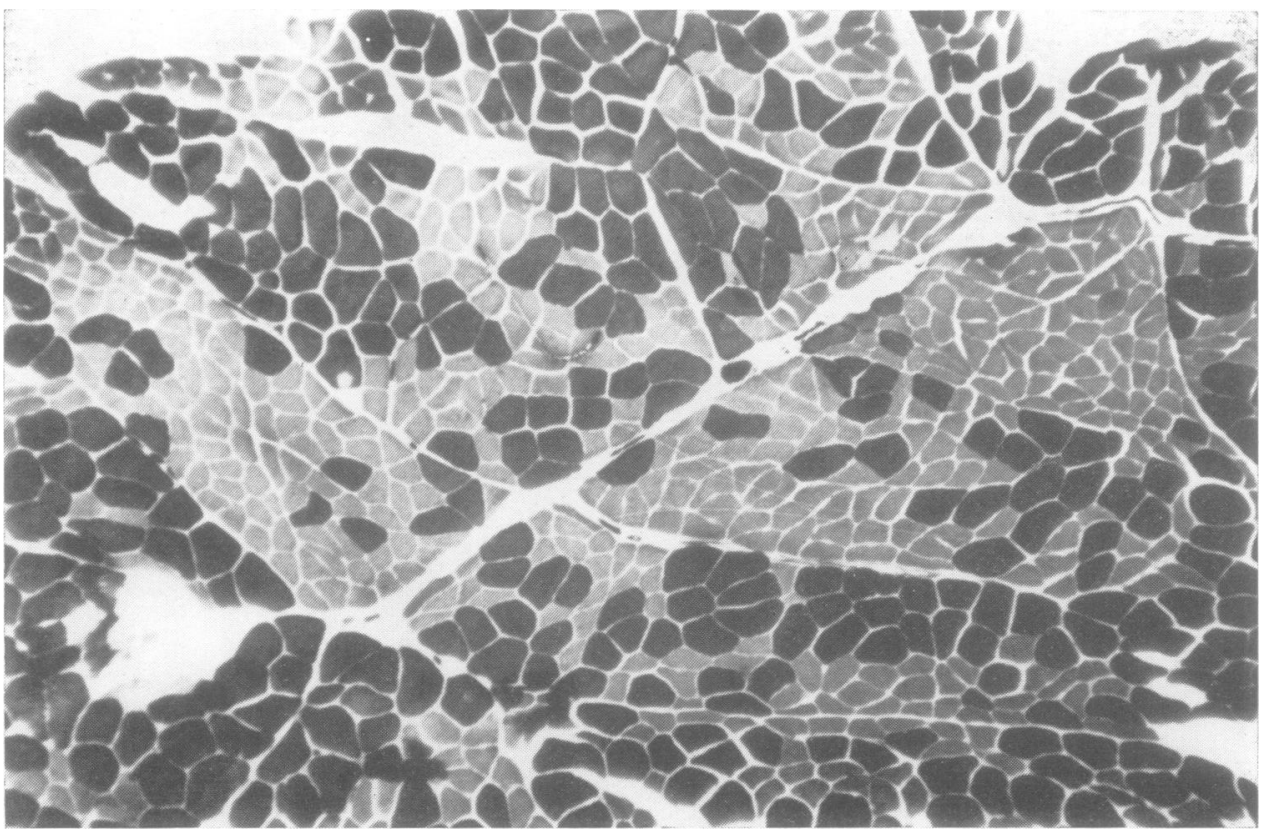

FIG. 5. Type grouping of the quadriceps muscle of a 45 year old man with a 20 year history of chronic alcoholism. ATPase, $\times 35$. 
TABLE

CLINICAL AND MUSCLE STUDY RESULTS

\begin{tabular}{|c|c|c|c|c|c|c|}
\hline \multicolumn{4}{|c|}{ Clinical } & \multicolumn{2}{|c|}{ Biopsy } & \multirow[t]{2}{*}{ Remarks } \\
\hline $\begin{array}{c}\text { Patient } \\
\text { Age Race/Sex }\end{array}$ & $\begin{array}{c}\text { Duration of } \\
\text { alcoholism }(y r)\end{array}$ & $D T s *$ & $\begin{array}{l}\text { Neurological signs } \\
\text { and symptoms }\end{array}$ & Morphology & Histochemistry & \\
\hline $41 \mathrm{~N} / \mathrm{M}$ & 15 & 1 & Normal & Normal & Normal & $\begin{array}{l}\text { EMG normal } \\
\text { Peroneal CV } 37.4 \mathrm{~m} / \mathrm{sec}\end{array}$ \\
\hline $65 \mathrm{~W} / \mathrm{M}$ & 40 & 12 & $\begin{array}{l}\text { Burning feet, } \\
\text { absent ankle } \\
\text { jerks }\end{array}$ & $\begin{array}{l}\text { Grouped atrophy } \\
\text { internal nuclei }\end{array}$ & $\begin{array}{l}\uparrow \text { Oxidative } \\
\downarrow \text { Phosphorylase } \\
\text { type II atrophy }\end{array}$ & BSP $12 \%$ \\
\hline $40 \mathrm{~N} / \mathrm{M}$ & 20 & 2 & Normal & $\begin{array}{l}\text { Grouped atrophy } \\
\text { ring fibres, } \\
\text { internal nuclei }\end{array}$ & $\uparrow \begin{array}{l}\text { Oxidative } \\
\text { Phosphorylase }\end{array}$ & BSP $8 \%$ \\
\hline $45 \mathrm{~W} / \mathrm{M}$ & 23 & 1 & Normal & Normal & Normal & \\
\hline $45 \mathrm{~W} / \mathrm{M}$ & 20 & 0 & Burning feet & $\begin{array}{l}\text { Grouped atrophy } \\
\text { necrotic fibres } \\
\text { internal nuclei }\end{array}$ & $\begin{array}{l}\uparrow \text { Oxidative } \\
\downarrow \text { Phosphorylase } \\
\text { targetoid fibres, } \\
\text { type grouping }\end{array}$ & Peroneal CV $41.2 \mathrm{~m} / \mathrm{sec}$ \\
\hline $42 \mathrm{~W} / \mathrm{M}$ & 20 & 3 & Normal & $\begin{array}{l}\text { Grouped atrophy } \\
\text { necrotic fibres }\end{array}$ & $\begin{array}{l}\uparrow \text { Oxidative } \\
\downarrow \text { Phosphorylase }\end{array}$ & Developed M.I. \\
\hline $61 \mathrm{~W} / \mathrm{M}$ & 40 & 0 & $\begin{array}{l}\text { Absent ankle } \\
\text { jerks }\end{array}$ & $\begin{array}{l}\text { Grouped atrophy } \\
\text { necrotic fibres }\end{array}$ & $\begin{array}{l}\uparrow \text { Oxidative } \\
\downarrow \text { Phosphorylase }\end{array}$ & \\
\hline $39 \mathrm{~W} / \mathrm{F}$ & 20 & 1 & $\begin{array}{l}\text { Diminished } \\
\text { ankle jerks }\end{array}$ & $\begin{array}{l}\text { Grouped atrophy } \\
\text { internal nuclei }\end{array}$ & $\begin{array}{l}\uparrow \text { Oxidative } \\
\downarrow \text { Phosphorylase } \\
\text { type II atrophy }\end{array}$ & $\begin{array}{l}\text { EMG neuropathic } \\
\text { Peroneal CV } 39.6 \mathrm{~m} / \mathrm{sec}\end{array}$ \\
\hline $45 \mathrm{~W} / \mathrm{M}$ & 16 & 2 & $\begin{array}{l}\text { Burning feet, } \\
\text { absent ankle } \\
\text { jerks }\end{array}$ & $\begin{array}{l}\text { Grouped atrophy } \\
\text { necrotic fibres } \\
\text { fat cells }\end{array}$ & $\begin{array}{l}\uparrow \text { Oxidative } \\
\downarrow \text { Phosphorylase } \\
\text { type grouping }\end{array}$ & $\begin{array}{l}\text { EMG neuropathic } \\
\text { Peroneal CV } 39 \cdot 1 \mathrm{~m} / \mathrm{sec}\end{array}$ \\
\hline $40 \mathrm{~W} / \mathrm{M}$ & 20 & 2 & Burning feet & $\begin{array}{l}\text { Grouped atrophy } \\
\text { internal nuclei }\end{array}$ & $\begin{array}{l}\text { Oxidative } \\
\text { Phosphorylase }\end{array}$ & \\
\hline $39 \mathrm{~W} / \mathrm{M}$ & 10 & 1 & Normal & Normal & Normal & EMG normal \\
\hline
\end{tabular}

Targetoid fibres, or the two-zoned target fibres of Engel, have a pale centre or core and a normallystained periphery. Because we have also found these fibres in the biopsies of patients with clear-cut peripheral neuropathy (as shown by clinical and electrodiagnostic studies), we agree with Engel's postulate (1966) that they may represent an unusual form of denervation. Similarly, we have seen type grouping (the segregation into contiguous groups of large numbers of fibres of the same histochemical type) in our patients with Charcot-Marie-Tooth disease and other chronic and less-defined forms of peripheral neuropathies associated with the hereditary spinocerebellar degenerations. Karpati and Engel (1968) convincingly demonstrated that section and immediate repair by suture of the guinea-pig sciatic nerve leads to type grouping of the gastrocnemius muscle. Thus, type grouping probably indicates reinnervation rather than denervation but we see no reason to discount it as a possible histochemical sign of denervation. Finally, we found selective type II reaction of the atrophic fibres, which, on the basis of our studies of the denervated quadriceps muscle of the hamster, we believe represents an intermediate phase in the progress of denervation from the time of nerve section.

We also discovered histological abnormalities which we believe are secondary myopathic changes of denervation: randomly distributed fibres with internal nuclei, necrotic fibres, ring fibres, and rows of fat cells replacing muscle fibres. In our previous study, we interpreted these same changes to be primary rather than secondary because we failed to see any histological proof of denervation. In this study, however, these myopathic changes were seen in muscle biopsies with denervation atrophy, suggesting that they are indeed secondary to denervation.

The electrodiagnostic studies of our patients also provided us with proof of denervation not only in their proximal muscles but also in their distal muscles. The quadriceps electromyograms showed distinct, though admittedly mild and patchily distributed, patterns of neuropathy. In four patients, including one who was asymptomatic, we found peroneal nerve conduction velocities which, when compared with an age-matched control group of 'social drinkers', appeared retarded.

Almost certainly, the presence of denervation has been proved in the proximal muscles of the present group of chronic alcoholics, a group which does not differ from our previously studied group. Both groups had well-documented histories of chronic alcoholism, the absence of any muscular weakness or wasting, a high incidence of distal hyporeflexic (ankle jerks) sensory neuropathy on clinical examination, slow nerve conduction velocities of their distal 
nerves, abnormal electromyograms of their proximal muscles, and muscle biopsy abnormalities of their proximal muscles.

But the two groups differ in the presence of denervation in the proximal muscles of the present group of chronic alcoholics, established by their patterns of neuropathy on electromyography and denervation atrophy on muscle biopsy. By proving denervation in their biopsies, we also proved that the accompanying myopathic changes (which were identical with those which we and others have described previously as primarily myopathic changes) are secondary to denervation.

We therefore conclude that muscle biopsy abnormalities in the proximal muscles of chronic alcoholics without muscle weakness or wasting are the result of denervation due to the well-known alcoholic peripheral neuropathy.

Dr. Bernard M. Abrams and Dr. Oscar E. Espinas performed the electrodiagnostic studies.

\section{REFERENCES}

Bauwens, P. (1961). Introduction to electrodiagnostic procedures. In Electrodiagnosis and Electromyography, pp. 171-200. Edited by S. Licht. Elizabeth Licht: New Haven.

Drachman, D. B., Murphy, S. R., Nigam, M. P., and Hills, J. R. (1967). 'Myopathic' changes in chronically denervated muscle. Arch. Neurol. (Chic.), 16, 14-24.

Ekbom, K., Hed, R., Kirstein, L., and Astrom, K. (1964). Muscular affections in chronic alcoholism. Arch. Neurol. (Chic.), 10, 449-458.

Engel, W. K., Brooke, M. H., and Nelson, P. G. (1966). Histochemical studies of the denervated and tenotomized cat muscle: illustrating difficulties in relating experimental animal conditions to human neuromuscular diseases. In Experimental Primary Myopathies and their Relationship to Human Muscle Disease. Edited by E. Bajusz. Ann. N.Y. Acad. Sci., 138, 160-185.
Engel, W. K., and Cunningham, G. C. (1963). Rapid examination of muscle tissue: an improved trichrome method for fresh-frozen biopsy sections. Neurology (Minneap.), 13, 919-923.

Engel, W. K. (1966). Multiplicity of pathologic reactions of human skeletal muscle. In Proceedings of the Fifth International Congress of Neuropathology (Zurich 1965), pp. 613-624. Edited by F. Luthy and A. Bischoff. Excerpta Medical Foundation: Amsterdam.

Faris, A. A., Reyes, M. G., and Abrams, B. M. (1967). Subclinical alcoholic myopathy: electromyographic and biopsy study. Trans. Amer. neurol. Assoc., 92, 102-106.

Hed, R., Lundmark, C., Fahlgren, H., and Orell, S. (1962). Acute muscular syndrome in chronic alcoholism. Acta med. scand., 171, 585-599.

Karpati, G., and Engel, W. K. (1968). 'Type grouping' in skeletal muscles after experimental reinnervation. Neurology (Minneap.), 18, 447-455.

Mancall, E. L., McEntee, W. J., Hirschhorn, A. M., and Gonyea, E. F. (1966). Proximal muscular weakness and atrophy in the chronic alcoholic. (Abstract.) Neurology (Minneap.), 16, 301.

Novikoff, A. B., Shin, W. Y., and Drucker, J. (1961). Mitochondrial localization of oxidative enzymes: Staining results with two tetrazolium salts. J. biophys. biochem. Cytol., 9, 47-61.

Padykula, H. A., and Herman, E. (1955). The specificity of the histochemical method for adenosine triphosphatase. J. Histochem. Cytochem., 3, 170-195.

Perkoff, G. T., Dioso, M. M., Bleisch, V., and Klinkerfuss, G. (1967). A spectrum of myopathy associated with alcoholism: I. Clinical and laboratory features. Ann. int. Med., 67, 481-492.

Perkoff, G. T., Hardy, P., and Velez-Garcia, E. (1966). Reversible acute muscular syndrome in chronic alcoholism. New Engl. J. Med., 274, 1277-1285.

Takeuchi, T. (1956). Histochemical demonstration of phosphorylase. (Letter to Editor.) J. Histochem. Cytochem., 4, 84 .

Taverner, D. (1961). Clinical applications of electromyography. In Electrodiagnosis and Electromyography, pp. 342-384. Edited by S. Licht. Elizabeth Licht: New Haven.

Wattenberg, L. W., and Leong, J. L. (1960). Effects of coenzyme $\mathrm{Q} 10$ and menadione on succinic dehydrogenase activity as measured by tetrazolium salt reduction. $J$. Histochem. Cytochem., 8, 296-303. 